\title{
New Dihydrobenzofuran Derivative, Awajanoran, from Marine-derived Acremonium sp. AWA16-1
}

\author{
Jae-Hyuk Jang, Kaneo Kanoh, Kyoko Adachi, Yoshikazu Shizuri
}

Received: May 11, 2006 / Accepted: June 29, 2006

(C) Japan Antibiotics Research Association

\begin{abstract}
Awajanoran (1), a new dihydrobenzofuran derivative, was isolated from an agar-culture of Acremonium sp. AWA16-1, which had been isolated from sea mud collected at Awajishima Island in Japan. The structure of $\mathbf{1}$ was elucidated on the basis of a spectroscopic analysis. This compound inhibited the growth of A549 cells, the human lung adenocarcinoma cell line, with an $\mathrm{IC}_{50}$ value of $17 \mu \mathrm{g} / \mathrm{ml}$, and also showed antimicrobial activity.
\end{abstract}

Keywords Awajanoran, Acremonium sp. AWA16-1, dihydrobenzofuran, cytotoxic, antimicrobial

Marine microorganisms have been drawing increasing attention as an important source of chemically interesting and biologically active secondary metabolites for the development of new pharmaceutical agents [1]. We have been screening marine-derived microorganism for their antimicroalgal, antibacterial and antitumor activities to find novel bioactive substances [2 4]. In the course of screening for antitumor substances, we detected activity in an extract of the marine-derived fungus, AWA16-1, which had been isolated from sea mud of Awajishima Island in Japan. This fungus (AWA16-1) was identified as Acremonium sp. from morphological studies and its $28 \mathrm{~S}$ rDNA sequence, and named Acremonium sp. AWA16-1. This strain has been deposited as NITE P-151 at the National Institute of Bioscience and Human-Technology of the Agency of Industrial Science and Technology, Japan.

J.-H. Jang (Corresponding author), K. Kanoh, K. Adachi, Y. Shizuri: Marine Biotechnology Institute Co. Ltd., 3-75-1 Heita, Kamaishi, Iwate 026-0001, Japan, E-mail: jang.jaehyuk@mbio.jp
Fungi belonging to the Acremonium genus are known to produce many interesting secondary metabolites, including orbuticin [5], acremolactones $\mathrm{A} \sim \mathrm{C}[6 \sim 8]$, acremonidin [9], halymecins [10], virescenosides [11 13], hydroquinone derivatives [14], and octapeptides [15]. We describe in this note the isolation, structural determination, and biological activities of awajanoran from the marinederived fungus.

The Acremonium sp. AWA16-1 fungus was cultured and kept on $50 \%$ SW-PDA (24 g of potato dextrose broth (Difco), $15 \mathrm{~g}$ of agar in 1.0 liter of $50 \%$ filtered natural seawater at $\mathrm{pH} 6.8$ before autoclaving). A small agar block bearing the mycelial growth of the producing strain was inoculated into the potato dextrose broth $(\mathrm{PDB}, 20 \mathrm{ml})$ in a $100 \mathrm{ml}$ Erlenmeyer flask, and then cultured at $25^{\circ} \mathrm{C}$ for 5 days with rotary shaking at $100 \mathrm{rpm}$. One $\mathrm{ml}$ of the seed culture was inoculated to the $400 \mathrm{ml}$ of $50 \%$-SW-PDA, which was prepared in stainless tray $(205 \times 266 \times 43 \mathrm{~mm})$. A total of 4 liters of the agar-culture was incubated at $25^{\circ} \mathrm{C}$ for 2 weeks. All 4 liters of this culture was extracted three times with an equal volume of acetone, the extract was passed through filter paper (Advantech No. 2), and the resulting filtrate was evaporated in vacuo, to give the acetone extract of the cultured fungus. This extract was partitioned between EtOAc and $\mathrm{H}_{2} \mathrm{O}$. The active EtOAc fraction was subjected to silica-gel column chromatography with $\mathrm{CHCl}_{3}, \mathrm{CHCl}_{3} / \mathrm{MeOH}(95: 5,9: 1$, and $8: 2)$ and $\mathrm{CHCl}_{3} / \mathrm{MeOH} / \mathrm{H}_{2} \mathrm{O}(6: 4: 1)$. The active fraction, $\mathrm{CHCl}_{3} / \mathrm{MeOH}$ (95:5), was separated by ODS flash

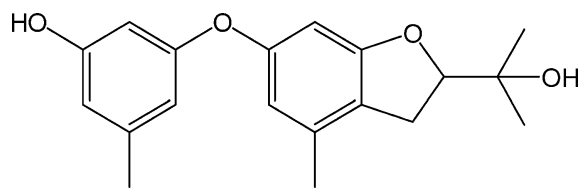

Fig. 1 Structure of awajanoran (1). 
Table 1 Physico-chemical properties of awajanoran (1)

\begin{tabular}{ll}
\hline Appearance & Colorless oil \\
Molecular formula & $\mathrm{C}_{19} \mathrm{H}_{22} \mathrm{O}_{4}$ \\
Molecular weight & 314 \\
FAB-MS $(\mathrm{m} / \mathrm{z})$ & $315[\mathrm{M}+\mathrm{H}]^{+}$ \\
HR FAB-MS $(\mathrm{m} / \mathrm{z})$ & \\
$\quad$ Found & $315.1622[\mathrm{M}+\mathrm{H}]^{+}$ \\
$\quad$ Calcd. & $315.1596[\mathrm{M}+\mathrm{H}]^{+}$ \\
{$[\alpha]_{D}^{25}$} & $-21(c 0.10, \mathrm{MeOH})$ \\
UV $\lambda_{\max } \mathrm{nm}(\log \varepsilon)$ in MeOH & $206(4.57)$ \\
IR $v_{\max }(\mathrm{KBr}) \mathrm{cm}^{-1}$ & $3447,1488,1147,1064,836$ \\
\hline
\end{tabular}

chromatography with $40 \sim 100 \% \quad \mathrm{MeOH} / \mathrm{H}_{2} \mathrm{O}$ and $\mathrm{CHCl}_{3} / \mathrm{MeOH} / \mathrm{H}_{2} \mathrm{O}(7: 3: 0.5$ and $6: 4: 1)$. The active fractions $\left(50 \%, 60 \%\right.$, and $\left.70 \% \quad \mathrm{MeOH} / \mathrm{H}_{2} \mathrm{O}\right)$ were combined and purified by HPLC (TSK gel ODS 80Ts, i.d. $2.0 \times 25 \mathrm{~cm}$, Tosoh Co.) with a linear gradient from $50 \%$ to $100 \% \mathrm{MeCN}$ containing $0.1 \%$ TFA. Final purification of the active fraction was performed by reversed-phase ODS HPLC in the same column with $65 \% \mathrm{MeOH}$ to afford awajanoran (1, 1.2 mg).

The physico-chemical properties of $\mathbf{1}$ are summarized in Table 1. Awajanoran (1) was obtained as colorless oil. The molecular formula was determined as $\mathrm{C}_{19} \mathrm{H}_{22} \mathrm{O}_{4}$ from HRFAB-MS data (see Table 1) in conjunction with the NMR spectra. The IR spectrum showed characteristic absorption bands at $3,447 \mathrm{~cm}^{-1}$, indicating the presence of a hydroxyl group in the molecule. The ${ }^{1} \mathrm{H}$ NMR spectrum exhibited signals for two aromatic methyl protons $(\delta 2.15$, $3 \mathrm{H}, \mathrm{s}$ and $2.17,3 \mathrm{H}, \mathrm{s})$, gem-dimethyl protons $(\delta 1.13,6 \mathrm{H}$, $\mathrm{s})$, one aromatic proton ( $\delta 6.30,1 \mathrm{H}$, brs), two pairs of meta-coupled aromatic protons $(\delta 6.12$ brs and 6.20 brs, and $6.17 \mathrm{~d}$ and $6.25 \mathrm{~d})$, one methylene proton $(\delta 3.00,2 \mathrm{H}$, $\mathrm{m})$, and an oxygenated methine proton $(\delta 4.56,1 \mathrm{H}$, dd). Additionally, two exchangeable ${ }^{1} \mathrm{H}$ signals were observed in DMSO- $d_{6}(\delta 9.35 \mathrm{~s}$ and $4.55 \mathrm{~s})$. The ${ }^{13} \mathrm{C}$ NMR and HSQC spectra indicated the presence of 19 carbons: seven nonprotonated $s p^{2}$ carbons ( $\delta 160.3,158.3,158.2,156.2$, $139.9,134.8$ and 121.6), one quaternary carbon $(\delta 70.0)$, five $s p^{2}$ methine carbons $(\delta 111.3,110.8,109.4,102.3$ and 98.0), one $s p^{3}$ methine carbon ( $\delta$ 89.7), one methylene carbon $(\delta 28.3)$, and four methyl carbons ( $\delta$ 25.9, 24.8, 21.1 and 18.6). The ${ }^{13} \mathrm{C}$ NMR spectrum displayed four signals at $\delta 160.3,158.3,158.2$ and 156.2, characteristic of aromatic carbon atoms attached to oxygen. These signals suggested 1,3,5-trisubstituted and 1,3,5,6-tetrasubstituted aromatic rings. Interpretation of the $2 \mathrm{D}$ NMR data including COSY, HSQC, HMBC and NOESY spectra, enabled the structure of $\mathbf{1}$ to be deduced (Fig. 2). HMBC
Table $2{ }^{1} \mathrm{H}$ and ${ }^{13} \mathrm{C}$ NMR spectral data for awajanoran (1) in DMSO-d

\begin{tabular}{|c|c|c|}
\hline Position & $\delta_{\mathrm{C}}$ & $\delta_{\mathrm{H}}$ \\
\hline 1 & 158.3 & \\
\hline 2 & 102.3 & 6.12 , brs \\
\hline 3 & 158.2 & \\
\hline $3-\mathrm{OH}$ & & $9.35, \mathrm{~s}$ \\
\hline 4 & 110.8 & $6.30, \mathrm{brs}$ \\
\hline 5 & 139.9 & \\
\hline 6 & 109.4 & $6.20, \mathrm{brs}$ \\
\hline 7 & 156.2 & \\
\hline 8 & 98.0 & $6.17, d, 2.5$ \\
\hline 9 & 160.3 & \\
\hline 10 & 121.6 & \\
\hline 11 & 134.8 & \\
\hline 12 & 111.3 & $6.25, d, 2.5$ \\
\hline 13 & 28.3 & $3.00, \mathrm{~m}$ \\
\hline 14 & 89.7 & $4.56, \mathrm{dd}, 9.3,8.3$ \\
\hline 15 & 70.0 & \\
\hline $15-\mathrm{OH}$ & & $4.55, \mathrm{~s}$ \\
\hline 16 & 24.8 & $1.13, \mathrm{~s}$ \\
\hline 17 & 25.9 & $1.13, \mathrm{~s}$ \\
\hline $18-\mathrm{CH}_{3}$ & 21.1 & $2.17, \mathrm{~s}$ \\
\hline $19-\mathrm{CH}_{3}$ & 18.6 & $2.15, \mathrm{~s}$ \\
\hline
\end{tabular}

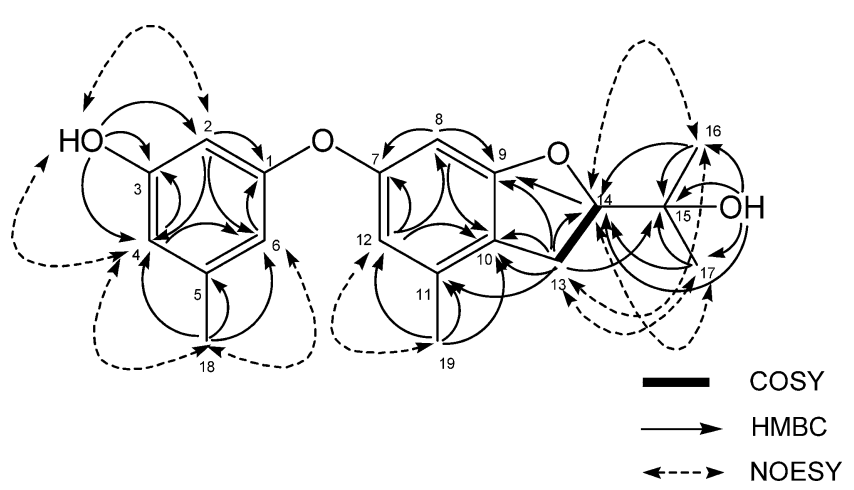

Fig. 2 2D-NMR correlations observed in awajanoran (1).

correlation peaks $(\mathrm{H}-2 / \mathrm{C}-1, \mathrm{C}-4$, and $\mathrm{C}-6$; H-4/C-3 and $\mathrm{C}-$ 6; H-6/C-1; OH-3/C-2, C-3, and C-4; $\mathrm{CH}_{3}-18 / \mathrm{C}-4$, C-5, and C-6; H-8/C-7, C-9, and C-10; H-12/C-7, C-8, and C-10; $\mathrm{CH}_{3}-19 / \mathrm{C}-10, \mathrm{C}-11$, and $\left.\mathrm{C}-12\right)$ and NOESY correlations (OH-3/H-2 and H-4; $\mathrm{CH}_{3}-18 / \mathrm{H}-4$ and $\mathrm{H}-6 ; \mathrm{CH}_{3}-19 / \mathrm{H}-12$ ) supported the substitution of two aromatic rings. The role of the remaining one oxygen atom would have been form the ether linkage between the two aromatic rings. The remaining signals of this compound exhibited the presence of the 1-hydroxy-1-methylethyldihydrofuran moiety $\left[\delta_{\mathrm{H}} / \delta_{\mathrm{C}}\right.$ 
Table 3 Antimicrobial activities of awajanoran (1)

\begin{tabular}{lc}
\hline \multicolumn{1}{c}{ Test organism } & Activity* $^{*}$ \\
\hline Escherichia coli IFO 3301 & - \\
Bacillus subtilis IFO 3134 & 10 \\
Staphylococcus aureus IFO 12732 & 18 \\
Salinivibrio costicola ATCC 33508 & 9 \\
Cytophaga marinoflava IFO 14170 & 8 \\
$\alpha$-Proteobacterium MBIC 3368 & 9 \\
Candida albicans IFO 1060 & 15 \\
\hline
\end{tabular}

* Diameter of the inhibitory zone in $\mathrm{mm}$ at $50 \mu \mathrm{g} /$ disk.

4.56/89.7 (oxymethine), 3.00/28.3 (methylene), 1.13/24.8 and 1.13/25.9 (gem-dimethyl), and $\delta_{\mathrm{C}} 70.0$ (oxygenated $s p^{3}$ carbon), 4.55 (tert-hydroxyl proton)]. The HMBC correlation peaks (H-13/C-14; $\mathrm{H}_{3}-16 / \mathrm{C}-14$ and $\mathrm{C}-15$; $\mathrm{H}_{3}-17 / \mathrm{C}-14$ and $\mathrm{C}-15 ; \mathrm{OH}-15 / \mathrm{C}-14, \mathrm{C}-15, \mathrm{C}-16$, and $\mathrm{C}-17)$ also supported the presence of the hydroxymethylethyldihydrofuran moiety. The HMBC correlation between the methylene protons $(\delta 3.00, \mathrm{H}-13)$ and $\mathrm{C}-9(\delta 160.3), \mathrm{C}-10(\delta 121.6)$ established the position of the dihydrofuran moiety to be at C-9 $\sim \mathrm{C}-10$. Thus, the structure of 1 was determined to be 3-[2-(1-hydroxy-1methyl-ethyl)-4-methyl-2,3-dihydro-benzofuran-6-yloxy]5-methyl-phenol, as new compound. The stereochemistry of the chiral center at C-14 has not yet been established.

The 2,3-dihydrobenzofuran moiety of $\mathbf{1}$ occurs in natural products including furowanin B [16], chiricanine E [17], brosimacutin E [18], and rautandiol B [19] have been isolated from plants and panaefluorolines $\mathrm{D} \sim \mathrm{H}[20]$ were isolated from the cultures mycobiont of a lichen, Amygdalaria panaeola. In addition, fungal metabolite F$11334 \mathrm{~A}_{2}$, have been isolated from fungus Acremonium sp. [21]. To our knowledge, absolute stereochemistry of these all compounds had not been determined for chiral center (C-14). We considered several methods to determine the absolute stereochemistry as foremost task.

The antimicrobial activity of awajanoran (1) was tested against six bacteria and Candida albicans by the paper disk method [22]. This compound showed moderate activity against five of the strains (Table 3), but showed no activity against the Gram-negative bacterium Escherichia coli. This compound also exhibited activity against Candida albicans and showed moderate cytotoxic activity [23] against A549 cells with an $\mathrm{IC}_{50}$ value of $17 \mu \mathrm{g} / \mathrm{ml}$, respectively.

Acknowledgment We thank Assistant Professor Ryuichi Sakai of Kitasato University for the HR-MS measurements. This work was performed as part of the project entitled "Constructing the
Genetic Resource Library of Unidentified Microbes Based on Genome Information" supported by New Energy and Industrial Technology Development Organization (NEDO).

References

1. Blunt JW, Copp BR, Murano MHG, Northcote PT, Prisep MR. Marine natural products. Nat Prod Rep 21: 1-49 (2004)

2. Kanoh K, Matsuo Y, Adachi K, Imagawa H, Nishizawa M, Shizuri Y. Mechercharmycins A and B, cytotoxic substances from marine-derived Thermoactinomyces sp. YM3-251. J Antibiot 58: 289-292 (2005)

3. Adachi K, Kanoh K, Wisespongp P, Nishijima M, Shizuri Y. Clonostachysins A and B, new anti-dinoflagellate cyclic peptides from a marine-derived fungus. J Antibiot 58: 145-150 (2005)

4. Yoshikawa K, Adachi K, Nishida F, Mochida K. Planar structure and antibacterial activity of koromicin derivatives isolated from Pseudoalteromonas sp. F-420. J Antibiot 56: 866-870 (2003)

5. Roy K, Chatterjee S, Deshmukh SK, Vijayakumar KSE, Ganguli NB, Fehlhaber HW. Orbuticin, a new secondary metabolite from Acremonium butyric. J Antibiot 49: 1186-1187 (1996)

6. Sassa T, Kinoshita $H$, Nukina $M$, Sugiyama $T$. Acremolactone A, a novel herbicidal epoxydihydropyranyl $\gamma$-lactone from Acremonium roseum I4267. J Antibiot 51: 967-969 (1998)

7. Sassa T, Ooi T, Kinoshita H. Isolation and structures of acremolactones B and C, novel plant-growth inhibitory $\gamma$ lactones from Acremonium roseum I4267. Biosci Biotechnol Biochem 68: 2633-2636 (2004)

8. Sassa T, Ooi T, Kinoshita H, Okada K. Absolute stereochemistry of acremolactones A, novel herbicidal epoxydihydropyranyl $\gamma$-lactones from Acremonium roseum I4267. Biosci Biotechnol Biochem 68: 2201-2204 (2004)

9. He H, Bigelis R, Solum EH, Greenstein M, Carter GT. Acremonidins, new polyketide-derived antibiotics produced by Acremonium sp. LL-Cyan 416. J Antibiot 56: 923-930 (2003)

10. Chen C, Imamura N, Nishijima M, Adachi K, Sakai M, Sano H. Halymecins, new antimicroalgal substances produced by fungi isolated from marine algae. J Antibiot 49: 998-1005 (1996)

11. Afiyatullov SS, Kuznetsova TA, Isakov VV, Pivkin MV, Prokof'eva NG, Elyakov GB. New diterpenic altrosides of the fungus Acremonium striatisporum isolated from a sea cucumber. J Nat Prod 63: 848-850 (2000)

12. Afiyatullov SS, Kalinovsky AI, Kuznetsova TA, Isakov VV, Pivkin MV, Dmitrenok PS, Elyakov GB. New diterpene glycosides of the fungus Acremonium striatisporum isolated from a sea cucumber. J Nat Prod 65: 641-644 (2002)

13. Afiyatullov SS, Kalinovsky AI, Kuznetsova TA, Pivkin MV, Pfrkof'eva NG, Dmitrenok PS, Elyakov GB. New 
glycosides of the fungus Acremonium striatisporum isolated from a sea cucumber. J Nat Prod 67: 1047-1051 (2004)

14. Abdel-Lateff A, Konig GM, Fisch KM, Holler U, Jones PG, Wright AD. New antioxidant hydroquinone derivatives from the algicolous marine fungus Acremonium sp. J Nat Prod 65: 1605-1611 (2002)

15. Boot CM, Tenney K, Valeriote FA, Crews P. Highly $N$ methylated linear peptides produced by an atypical spongederived Acremonium sp. J Nat Prod 69: 83-92 (2006)

16. Ito $\mathrm{C}$, Itoigawa $\mathrm{M}$, Kumagaya $\mathrm{M}$, Okamoto $\mathrm{Y}$, Ueda $\mathrm{K}$, Nishihara T, Kojima N, Furukawa H. Isoflavonoids with antiestrogenic activity from Millettia pachycarpa. J Nat Prod 69: 138-141 (2006)

17. Ioset JR, Marston A, Gupta MP, Hostettmann K. Five new prenylated stilbenes from the root bark of Lonchocarpus chiricanus. J Nat Prod 64: 710-715 (2001)

18. Takashima J, Ohsaki A. Brosimacutins A I, nine new flavonoids from Brosimum acutifolium. J Nat Prod 65: 1843-1847 (2002)

19. Sakurai Y, Sakurai N, Taniguchi M, Nakanishi Y, Bastow KF, Wang X, Cragg GM, Lee KH. Rautandiols A and B, pterocarpans and cytotoxic constituents from Neorautanenia mitis. J Nat Prod 69: 397-399 (2006)

20. Kinoshita K, Yamamoto Y, Takatori K, Koyama K, Takahashi K, Kawai K, Yoshimura I. Fluorescent compounds from the cultured mycobiont of Amygdalaria panaeola. J Nat Prod 68: 1723-1727 (2005)
21. Masahiro T, Futoshi N, Yamasato Y, Ono Y, Ogita T. F$11334 \mathrm{~s}$, new inhibitors of membrane-bound neutral sphingomyelinase. J Antibiot 52: 827-830 (1999)

22. The antimicrobial activities against seven species of microorganisms were measured by the paper disk method. Nutrient Broth agar (Difco) was used as the medium for growing Escherichia coli IFO 3301, Bacillus subtilis IFO 3134, Staphylococcus aureus IFO 12732, and Candida albicans IFO 1060, while Marine Broth agar (Difco) was used for Salinivibrio costicola ATCC 33508, Cytophaga marinoflava IFO 14170 , and $\alpha$-Proteobacterium MBIC 3368. Sample was applied to a paper disk (i.d. $6 \mathrm{~mm}$ ) at a dose of $50 \mu \mathrm{g} / \mathrm{disk}$, and the paper disk was then air-dried. The impregnated paper disk was placed on the surface of an agar plate seeded with on of the microbial strains. The growth inhibition zone was measured after 48 hours of incubation at $30^{\circ} \mathrm{C}$.

23. A549 cells were cultured in a DMEM medium supplemented with $10 \%$ fetal bovine serum. The cells were seeded $(4,000$ cells/well in $200 \mu \mathrm{l})$ in 96-well microplates and then cultured in a $\mathrm{CO}_{2}$ incubator $\left(5 \% \mathrm{CO}_{2}\right.$ - air, $\left.37^{\circ} \mathrm{C}\right)$ for 14 hours. Serially diluted samples were added to each well, and the cells were cultured for a further 48 hours. The cell number was counted by the Alamar Blue ${ }^{\mathrm{TM}}$ method, and the $\mathrm{IC}_{50}$ value was determined from three independent experiments. 